\title{
THE RELATIONSHIP BETWEEN LEG LENGTH, LEG MUSCLE EXPLOSIVE POWER AND THE ABILITY TO RUN 100 METER SPRINT FOR MALE STUDENTS IN CLASS X AT SMAN 2 SELUMA
}

\author{
Alexon $^{1}$, Santun Sihombing ${ }^{2}$, Wiwik Yunitaningrum ${ }^{3}$, Julio Dwi Putra ${ }^{4}$ \\ ${ }^{124}$ Physical Education, Universitas Bengkulu, Bengkulu, Indonesia \\ ${ }^{3}$ Recreational Health Physical Education, Universitas Tanjungpura, Kalimantan Barat, \\ Indonesia
}

\section{Article Info}

Article History :

Received : November 2021 Revised : November 2021 Accepted : December 2021 Available online : December 2021

\section{Keywords:}

Leg Length, Explosive Power, Sprint 100 Meters

\begin{abstract}
The purpose of this study was to determine the relationship between limb length, leg muscle explosive power and the ability to run 100 meters sprint in male students of class $X$ in SMAN 2 Seluma. This type of research is multiple correlation research. The population in this study were the sons of class $\mathrm{X}$ at SMAN 2 Seluma totaling 65 students. sampling technique is purposive sampling the number of samples is 40 people. The instruments used were leg length measurement, vertical jump test and sprint 100 meterFrom the calculation results, the conclusion in this study is that there is a very strong relationship between leg length and the ability to run sprint 100 meterThere is a very strong relationship between leg muscle explosive power and the ability to run sprint 100 metersthere is a very strong relationship between leg length, leg muscle explosive power and the ability to run sprint in male students of class $\mathrm{X}$ at SMAN 2 Seluma.
\end{abstract}




\section{INTRODUCTION}

Humans as individuals are a combination of two elements consisting of physical and spiritual. The two elements cannot be separated and form a unified whole, so the two elements must be properly nurtured in order to realize a complete individual.

As a form of implementation of achieving national education is the implementation of physical education and sports at all levels of education. The implementation of physical education is a long-term investment in efforts to develop the quality of Indonesian human resources. Physical education aims to help children grow and develop naturally in accordance with the goals of national education, namely to become fully Indonesian human beings (Rosdiani, 2013). In addition, physical education also aims to develop the psychomotor, cognitive, affective, social, and emotional aspects of students (Nopiyanto, \& Raibowo, 2019).

The importance of the quality of teaching staff and supporting infrastructure to realize educational goals, especially in physical education, sports and health, which have an important role in the growth and development of students, must really be considered (Raibowo \& Nopiyanto, 2020)

Athletics is a physical activity or physical exercise, containing natural and natural movements in accordance with what is carried out in our daily lives such as walking, running, throwing, and jumping. Atleti comes from the Greek word "Athlon" which means to compete or compete. The term athlon is usually used for the word "pentathlon" or "decathlon". Pentahtlon means five races or five types of competitions consisting of 200-meter freestyle swimming, 3200-meter crosscountry running, fencing, shooting, and 15 -jump hurdles. While decathlon means ten races or 10 types of competitions, namely the 100 meter run, 400 meter run, 110 meter hurdles run, 1500 meter run, long jump, shot put, discus throwing, high jump, pole high jump, and javelin throwing (Nopiyanto et al. ., 2020).

Movement activities in athletics are not only used for achievement purposes but are also used to maintain one's health and physical fitness. Athletics is a special sport, especially in walking and running. We can find this in everyday life, many people fill their spare time on holidays by walking and running (Nopiyanto \& Raibowo, 2020).

Sprint is an athletic sport that uses one element of physical fitness, namely speed. Where short distance running (sprint) participants or students run at full speed along the distance that must be covered. It is called a short distance run because the distance covered is short or close. Someone who has an average height posture also has long legs, so the center of gravity of the body is high, this means that the base height is also high. Thus, the distance between the height of the anvil and the height of the bar will be shorter than that of a short person. The length of the leg itself is the distance from the groin to the heel. When running sprints, leg muscle power plays a very important role. Widiastuti (2011) "explosive power or power is a combination of strength and speed or the influence of maximum muscle force with maximum speed".

Running is a forward movement to move the body as quickly as possible, both legs are there when floating and not attached to the ground or floor (Sihombing, 2019). In sprint technique and arrangement of the elements of the run must be perfect, because the slightest mistake will reduce the time achieved. In accordance with the purpose of running sprints, the basic requirement in short distance running is speed "speediswhat is needed for all sprint and hurdle events in accordance with the understanding that 
sprint means running with the fastest repulsion". Sprinting develop elements of speed and muscle strength. So that the strength of the frequency of footsteps is needed by exerting the strength and speed of the step with a maximum contraction (Ariasti, 2019).

The ability to run sprints is determined by the length of the steps and the frequency of the steps that are produced by one's legs. Runners with longer legs run faster than those with short legs. Because the size of the long legs in running will result in a longer stride. Runners who have leg power and have strong leg lengths are able to run more maximally. In the end it took less time to reach a distance of 100 meters. Students can run faster, if their proportions and biomotor abilities are good.

Athletics is a daily human activity that is developed into playing and sports activities which are contested in the form of running, throwing and jumping. Therefore, to facilitate the learning process that is carried out well and learning indicators can run well. However, not all schools have complete facilities and infrastructure.

Based on my observations at SMA Negeri

2 Seluma, that the facilities and infrastructure are quite complete, namely futsal field, soccer field, volleyball, basketball, sepak takraw, table tennis and other facilities. athletic infrastructure.

Based on the background description of the sprint of SMA Negeri 2 Seluma students not yet showing optimal performance, students' running steps are not stable and the results of the sprint are not optimal, this can be seen from the results of sprint which is still less than 15.07 seconds. The reaction time is still slow in doing the star, students do not know the basic techniques in sprinting, lack of understanding of students about what factors are related to the ability to run sprints, students do not know the role of leg muscle explosive power when doing stars, there is no research on the relationship between leg length and leg muscle explosive power with the ability to run sprint for male students in class $\mathrm{X}$ at SMA Negeri 2 Seluma. Therefore, the researcher wanted to find out whether there was a relationship between leg length and leg muscle explosive power with the ability to run 100 meter sprints for male students in class $X$ at SMA Negeri 2 Seluma.

\section{METHODS}

This research is a type of correlational research for the relationship between the independent variable $(\mathrm{X})$ and the dependent variable $(\mathrm{Y})$, the independent variables are leg length, leg muscle explosive power and the dependent variable is the ability to run sprint 100 metersand the design of this research is by using tests and measurements. According to Arikunto (2010) correlational research aims to find out whether there is a relationship and if there is, how big is the relationship and whether or not the relationship is meaningful. The population in this study was 65 male students in class $X$ SMA Negeri 2 Seluma. Researchers here took a sample of 40 male students in class X.

According to Kristanto (2018) research instruments are data collection tools used by researchers to collect research data in accordance with the data collection techniques that have been selected. In this study using 3 instruments, namely the measurement of leg length, measurement of leg muscle explosive power and the ability to run sprint 100 metersData analysis is an important step in a research. After all the data has been collected, the next step is to analyze the data so that a conclusion can be drawn. Before the analysis is carried out so that the conclusions obtained can be justified, it is necessary to carry out prerequisite tests: 
Normality Test, Homogeneity Test, Multiple Correlation Analysis.

Table 1.

\begin{tabular}{cc}
\hline $\begin{array}{c}\text { Interval Correlation } \\
\text { Coefficient }\end{array}$ & $\begin{array}{c}\text { Interpretation } \\
\text { Relationship }\end{array}$ \\
\hline $0.80-1.00$ & Very Strong \\
\hline $0.60-0.79$ & Strong \\
\hline $0.40-0.59$ & Strong enough \\
\hline $0.20-0.39$ & Low \\
\hline $0.00-0.19$ & Very Low
\end{tabular}

\section{RESULT}

\section{Leg Length (X1)}

The maximum score $=96$; minimum value $=83 ;$ mean $=87.63$; standard deviation $=2.66$. Furthermore, it is arranged in a frequency distribution, which is looking for the number of interval classes $(1+3,3 \log N)$, the data range (maximum value - minimum value), and the length of the interval class (range/many interval classes). The following table shows the frequency distribution of the variable leg lengths obtained.

Table 2. Frequency distribution

\begin{tabular}{ccc}
\hline Internal & Frequency & Percentage \\
\hline $83-84$ & 5 & $12.5 \%$ \\
\hline $85-86$ & 6 & $15 \%$ \\
\hline $87-88$ & 14 & $35 \%$ \\
\hline $89-90$ & 12 & $30 \%$ \\
\hline $91-92$ & 1 & $2.5 \%$ \\
\hline $93-94$ & 1 & $2,5 \%$ \\
\hline $95-96$ & 1 & $2.5 \%$ \\
\hline TOTAL & 40 & $100 \%$ \\
\hline
\end{tabular}

Limb Muscle Explosive Power (X2)

The highest score was obtained $=56$; lowest value $=45 ;$ mean $=49.15$; and standard deviation $=2.43$. Furthermore, it is arranged in a frequency distribution, which is looking for the number of interval classes $(1+3,3 \log N)$, the data range (maximum value - minimum value), and the length of the interval class (range/many interval classes). The following table shows the frequency distribution of the variable leg muscle explosive power obtained.

Table 3. Frequency distribution of leg muscle explosive power.

\begin{tabular}{ccc}
\hline Interval & Frequency & Percentage \\
\hline $45-46$ & 5 & $12.5 \%$ \\
\hline $47-48$ & 11 & $27.5 \%$ \\
\hline $49-50$ & 15 & $37.5 \%$ \\
\hline $51-52$ & 5 & $12.5 \%$ \\
\hline $53-54$ & 3 & $7.5 \%$ \\
\hline $55-56$ & 1 & $2.5 \%$ \\
\hline Total & 40 & $100 \%$ \\
\hline
\end{tabular}

\section{Speed Sprint 100 Meters (Y)}

Highest score $=19.85$, the lowest score $=14.87$, the average $=17.217$ and the standard deviation $=1.81$. Furthermore, it is arranged in a frequency distribution, which is looking for the number of interval classes $(1+3,3 \log N)$, the data range (maximum value - minimum value), and the length of the interval class (range/many interval classes). The following table shows the frequency distribution of the variable leg muscle explosive power obtained. 
Table 4. Frequency distribution of 100 meter sprint running speed.

\begin{tabular}{ccc}
\hline Interval & Frequency & Percentage \\
\hline $14.87-15.58$ & 13 & $32.5 \%$ \\
\hline $15.59-16.3$ & 5 & $12.5 \%$ \\
\hline $16.31-17.2$ & 3 & $7.5 \%$ \\
\hline $17.3-17.74$ & 3 & $7.5 \%$ \\
\hline $17.75-18.46$ & 7 & $17.5 \%$ \\
\hline $18.47-19.18$ & 9 & $22.5 \%$ \\
\hline Total & 40 & $100 \%$ \\
\hline
\end{tabular}

\section{DISCUSSION}

\section{Ability Sprint 100 Meter}

Based on the results of the calculations that have been carried out, it can be seen that there is a significant relationship between the variables in this study. The first calculation is to find the relationship between leg length and the ability to run sprint 100 meterThe result is that leg length has a significant impact or relationship on the speed of sprint 100 meterThe calculated $\mathrm{r}$ value obtained is 0.885 which is in the range between 0.80 1.00 with a very strong category. The limbs are the lower limbs that comprise the entire leg. Leg length is related to the stride distance in one leg swing. with long legs, the more steps used in units of distance, the less Iqbal (2019).

This study was supported by several previous researchers such as that of Pradana (2019) who explained that based on the results of data analysis, the contribution of leg length to the ability to run sprints was $67.89 \%$. This proves that leg length has a high enough contribution to the sprint 's 100 meter

Munfa'atin (2018) in his research explained that based on the results of the analysis showed that there was a significant relationship between leg length and running speed of 60 meters in upper- class male students at SD Negeri 05 Karangtalun Cilacap, with a value of $\mathrm{rxy}=$ $0.642>\mathrm{r}$ table $=0.259$. The contribution of leg length to the 60 meter run is $32.05 \%$.

In conclusion, the limbs of each individual have different sizes so that it affects the running speed of each individual. The longer a person's limbs allow a person to go further and more efficiently so that it can help achieve maximum speed.

\section{The Relationship Sprint}

Between the explosive power of the limb muscles and the ability to run 100 metersThe calculated $r$ value obtained is 0.919 which is in the range between 0.80 1.00 with a very strong category. This means that the explosive power of the leg muscles has a great relationship with the ability to run sprint 100 meterExplosive power is a combination of strength and speed or the influence of maximum muscle force with maximum speed (Widiastuti, 2011). With a strong explosive power, the thrust when starting and running will be stronger, thus running faster.

Tobrani (2016) in his research explained that based on the results of the analysis showed that there was a relationship between leg muscle strength and 50 meter short distance running which was quite strong.

Iqbal (2019) in his research explains that based on the results of the analysis, there is a significant relationship between the explosive power of the leg muscles and the ability to run sprints 100 meterWith a calculated $r$ value of $=0.497$, it is in the range between $0.40-0.599$ with a sufficient category.

In conclusion, a person's leg power is not the same, some are high and some are low, the level of one's leg power will affect his running speed. Someone who has high leg power will easily develop his running speed, both in reaction speed (at the start), movement acceleration (in the 
first few meters), basic speed (as maximum speed) and in speed stamina (speed endurance). For someone who has high leg power will produce a higher stride frequency and a longer stride length when running compared to someone who has a low stride frequency. This is very useful for achieving maximum speed while running, because running speed is the result of a person's stride frequency and stride length.

\section{Relationship between Leg Length, Explosive Power of Limb Muscles with Sprint 100 Meters}

In the third calculation, the double correlation index obtained a value of $r$ of 0.89 and lies in the range between 0.801.00 with a very strong category, it means a combination of limbs. long and supported by the explosive power of strong leg muscles will support maximum running speed. Leg length is related to the distance in one leg swing, with long legs and the stronger the explosive power of the leg muscles, the better the sprint speed will be. Iqbal (2019).

From the analysis carried out, it can be seen that the calculated $F$ value obtained is 70.72 with $\mathrm{dk}=2$ versus 37 because at a significant level of 5\% the $\mathrm{F}$ table value is 3.25 because $F$ arithmetic is $70.72>\mathrm{F}$ table 3.25. From these results, it can be concluded that there is a significant relationship between leg length, leg muscle explosive power and the ability to run sprint 100 metersThus, the hypothesis which states that there is a relationship between leg length, explosive power of leg muscles and the ability to run sprints for male students in class $X$ at SMA Negeri 2 Seluma, can be accepted as true.

Munfa'atin (2018) explains that based on the results of the analysis, it shows that there is a significant relationship between leg length and leg power with a running speed of 60 meters in upper-class male students at SD Negeri 05
Karangtalun Cilacap, with a value ofrxxy= $0.759>\mathrm{r}$ table $=0.259$ the contribution of leg length and leg power to the 60 meter running speed is $57.70 \%$.

In the same study, Iqbal (2019) explained that based on the results of the analysis showed that there was a significant relationship between leg muscle explosive power and leg length on the results of sprint, the double correlation index value $=0.583$ and lies in the range between $0.40 \quad-0.599$ with enough category. Similar research results also state that there is a relationship between leg muscle power and leg length with sprint running results (Sihombing, 2019).

In conclusion, someone who has long legs and high leg power will produce a higher stride frequency and longer stride length when running compared to someone who has a low stride frequency. This is very useful for achieving maximum speed when running, because running speed is the result of a person's step frequency and stride length. Strong leg muscles and supported by long legs will support maximum sprint .

\section{CONCLUSION}

Based on the research results obtained from this study, it can be concluded as follows:

1. There is a very strong relationship between leg length and the ability to run sprint in male students of class $\mathrm{X}$ at SMA Negeri 2 Seluma.

2. There is a very strong relationship between leg muscle explosive power and the ability to run sprints in $\mathrm{X}$ grade male students at SMA Negeri 2 Seluma.

3. There is a very strong relationship between leg length, leg muscle explosive power and the ability to run .100 meters sprint in class $X$ male students at SMA Negeri 2 Seluma 


\section{REFERENCES}

Ariasti, H, K. (2016). Hubungan Panjang Tungkai dan Kekuatan Otot Tungkai dengan Kecepatan Lari Atlet Sprint [skripsi]. Jawa Tengah (ID) : Universitas Muhammaddiyah Surakarta.

Iqbal, Muhammad. (2019)., Hubungan Daya Ledak Otot Tungkai Dan Panjang Tungkai Terhadap Kemampuan Lari Sprint 100 Meter Pada Siswa Kelas XI SMA Taruna Mandiri Pekan Baru [skripsi]. Riau (ID) : Universitas Islam Riau.

Kartini, D. N., Sukirno, S., \& Waluyo, W. (2020). Hubungan Kelentukan Togok Dan Panjang Tungkai Dengan Kecepatan Lari Sprint Siswa Kelas" Vii" Smp Negeri 31 Palembang (Doctoral Dissertation, Sriwijaya University).

Kristanto, V, H. (2018). Metodologi Penelitian. Yogyakarta : CV Budi Utama.

Munfa'atin, Irma. (2018) Hubungan Panjang Tangkai Dan Power Tungkai Terhadap Kecepatan Lari 60 Meter Pada Siswa Laki-Laki Kelas Atas DI SD Negeri 05 Karangtalun Cilacap Tahun Ajaran 2017/2018 [skripsi]. Yogyakarta (ID) : Universitas Negeri Yogyakarta.

Lamusu, A., Mile, S., \& Lamusu, Z. (2022). Hubungan Power Otot Tungkai Dengan Kecepatan Lari Jarak Pendek. Jambura Journal Of Sports Coaching, 4(1), 1-9.

Nopiyanto, Y, E. et al. (2020). Pembelajaran Atletik. Bengkulu : Elmarkazi.

Nopiyanto, Y. E., \& Raibowo, S. (2019). Filsafat Pendidikan Jasmani \& Olahraga. Bengkulu: Zara Abadi.

Nopiyanto, Y. E., \& Raibowo, S. (2020). Dasar-Dasar Atletik. Bengkulu: Elmarkazi.

Pradana, A, A. (2013). Panjang Tungkai Terhadap Kecepatan Lari (Sprint) 100 Meter Putra Universitas Negeri Surabaya Jurusan Pendidikan Kesehatan Dan Rekreasi Prodi S1 Ilmu Keolahragaan. I- Journal Kesehatan Olahraga, 2.

Raibowo, S \& Nopiyanto, Y. E. (2020). Evaluasi Pembelajaran Pendidikan Jasmani Olahraga \& Kesehatan Pada
SMP Se-Kabupaten Mukomuko Melalui Pendekatan Model Context, Inputn Process \& Product (CIPP). Jurnal Pendidikan Kesehatan Rekreasi, 6(2), 146-165.

Rosdiani, D., (2013). Model Pembelajaran Langsung Dalam Pendidikan Jasmani dan Kesehatan. Bandung: alfabeta.

Sihombing, Santun. (2019). Hubungan Panjang Tungkai Dan Daya Ledak Otot Tungkai Dengan Hasil Lari Sprint 100 Meter. Kinestetik: Jurnal Ilmiah Pendidikan Jasmani, 3(2), 256-261.

Tobrani. (2016). Hubungan Antara Kekuatan Otot Tungkai, Tinggi Badan, dan Ligkar Paha dengan Kecepatan Lari Jarak Pendek 50 Meter Pada Siswa Putra SMP Swadhipa 1 Natar Lampung Selatan.[skripsi]. Bandar Lampung (ID) :Universitas Lampung

Widiastuti. (2011). Tes dan Pengukuran Olahraga. Jakarta Timur: PT. Bumi Timur Jaya. 